\title{
Geochemical Comparison of Fresh and Weathered Tailings from the Sabodala Gold Mine Kedougou Region, Senegal Following 6 Years of Operation
}

\author{
Ibrahima Dia1, Mababa Diagne1, Mamadou Gueye1, Andrew Barnes², Christian Mace ${ }^{3}$ \\ ${ }^{1}$ Earth Sciences Institute, Cheikh Anta Diop University, Dakar, Senegal \\ ${ }^{2}$ Geochemic Ltd., Monmouthshire, United Kingdom \\ ${ }^{3}$ Teranga Gold Corporation, Toronto, Canada \\ Email: ibrahima4.dia@ucad.edu.sn
}

How to cite this paper: Dia, I., Diagne, M., Gueye, M., Barnes, A., \& Mace, C. (2020). Geochemical Comparison of Fresh and Weathered Tailings from the Sabodala Gold Mine Kedougou Region, Senegal Following 6 Years of Operation. Journal of Geoscience and Environment Protection, 8, 177-194. https://doi.org/10.4236/gep.2020.87010

Received: July 1, 2020

Accepted: July 26, 2020

Published: July 29, 2020

Copyright $\odot 2020$ by author(s) and Scientific Research Publishing Inc. This work is licensed under the Creative Commons Attribution International License (CC BY 4.0).

http://creativecommons.org/licenses/by/4.0/

\section{Open Access}

\begin{abstract}
The Sabodala gold mine is located in the Kedegou region in eastern Senegal near the border with Mali in a tropical Savannah climate zone with distinct wet and dry seasons. The mine has been operating since 2009 with active tailings deposition giving an ideal opportunity to study the weathering characteristics of carbonate rich tailings materials under real world conditions. The mine is operated in accordance with international best practice with regular monitoring of water quality and tailings chemistry in accordance with the international cyanide management code (ICMC) and also in order to monitor and control any potential impacts from Acid Rock Drainage and Metal Leaching (ARDML) that may be generated from the tailings materials and waste rock. In 2015 as part of a project looking at the potential for re-use of generated tailings as construction materials, a number of additional geochemical tests including whole rock assays, mineralogy, Acid Base Accounting in accordance with modified Sobek method with siderite correction, together with paste $\mathrm{pH}$ and electrical conductivity $(\mathrm{Ec})$ measurements were undertaken. The purpose of the study was to update the predictions of the potential for ARDML generation and drainage $\mathrm{pH}$ in leachates forming from the Sabodala tailings. The tests were run on one composite weathered and 3 selective fresh samples collected by auger drilling on three holes over the tailing. Results have enabled a better understanding of the chemical weathering characteristics of finely ground tailings materials under tropical weathering conditions and the nature of secondary minerals precipitated.
\end{abstract}




\section{Keywords}

Acid Base Accounting, Neutralization Potential, Elemental Analysis, Mineralogy

\section{Introduction}

The Sabodala gold mine in the Kedegou region of eastern Senegal is operated by Sabodala Gold Operations (SGO), a subsidiary of Teranga Gold Corporation. The mine is operated according to world best practices with respect to health, safety and environment. On a regular basis, the integrity of the Tailing Storage Facility (TSF) is surveyed and the tailings are assayed and analysed to monitor their interactions with the environment.

A critical aspect of the monitoring of the tailings is the prediction of the future $\mathrm{pH}$ of their drainage in order to assess possibilities of occurrence of Acid Rock Drainage and Metal Leaching (ARDML) which can be highly harmful to the environment in case where conditions for ARDML generation are favourable. In these cases, measures must be taken to manage the ARDML risk through engineered methods.

In order to be able to predict the behaviour of tailings materials in terms of their potential to generate ARDML, it is necessary to be able to build a full understanding of how the tailings material will behave once placed in a tailings impoundment. However, this is by no means an easy task as every mine site has a unique set of interrelated geological/mineralogical/climatological and metallurgical conditions which means that every tailings facility will weather uniquely.

It is possible to narrow down the behaviour of the particular tailings material in order to make an educated prediction of ARDML risk by undertaking robust geochemical characterisation testing, understanding the mineralogy of the materials, understanding the geology, climatic conditions and then tying these back to previous experience and literature values.

The following study aims to shed some light on the weathering behaviour of tailings in one such case study.

\section{Site Description}

\subsection{General Setting}

Sabodala mine is located in the Kedougou region of south eastern Senegal; approximately $850 \mathrm{~km}$ east of the capital Dakar (Figure 1) at the coordinates $13.186813 \mathrm{~N} / 12.111441 \mathrm{~W}$.

The local climate is of soudano-guinean, or tropical Savannah, in accordance with the Koppen classification (Peel et al., 2007) with a local average insolation of 2950 hours per annum and average temperatures ranging from $22.8^{\circ} \mathrm{C}$ to $34.8^{\circ} \mathrm{C}$. The rainy season runs from May to October with an average of $1248 \mathrm{~mm}$ of rain per annum mainly falling within the rainy season (TROPICA, 2006). 


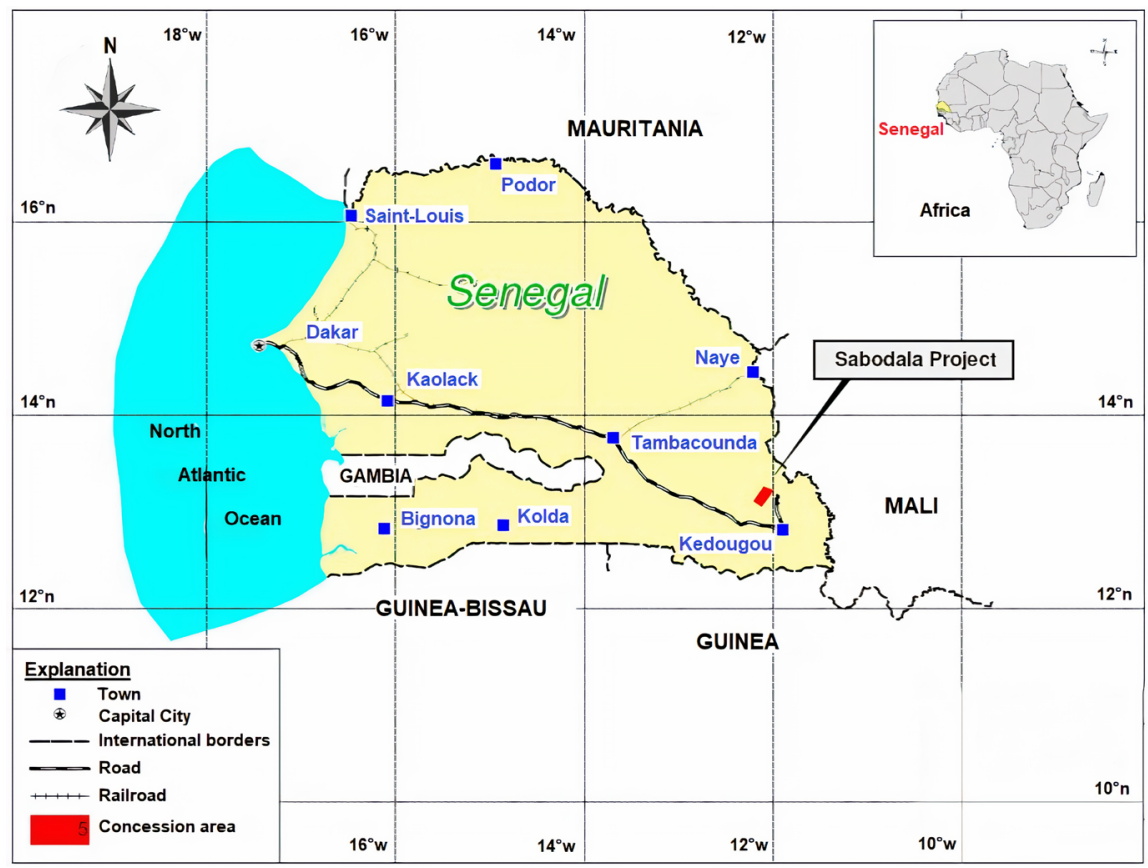

Figure 1. Location map of the Sabodala project.

\subsection{Geological Setting}

The Sabodala gold mine is situated within the West African Birimian greenstone geological gold belt in a region of orogenic shearing. The deposit belongs to the Senegal-Mali border basement named Kedougou Keniaba inlier (KKI) which is the west most part of the West African Craton.

Regional mapping indicates that the Senegalese portion of the KKI contains two units separated by a major shear zone named Main Transcurrent Zone (Hirdes \& Davis, 2002):

- a northeast trending volcanic belt named Mako which is associated with Na-rich granitoid stocks,

- a metasedimentary basin named Diale-Dalema and containing the extensive syn- to late-kinematic K-rich Saraya batholith and other basin-type plutons.

The Mako belt to which belongs the Sabodala deposit has been structured between 2.2 and $2 \mathrm{Ga}$ and has recorded at least four main deformation phases (Gueye et al., 2008). Figure 2 shows the geological setting of KKI inlier.

The Kedougou Keniaba inlier is hosting multiple word class deposits being currently, for most of them, exploited (Figure 3).

The Sabodala deposit is hosted by a north-northeast trending and steeply northwest dipping sequence of mafic volcanic and volcaniclastic rocks, gabbro, cherty to siliciclastic sediments, and structurally late felsic dykes (Rhys, 2010). All these lithologies may host the gold mineralization but the most extensive mineralized areas are localised in the volcaniclastic rocks and cherty sediments for the fresh part (Stephenson et al., 2010). For the oxidised part, in addition to these facies, more ultramafic mineralised rocks are noted.

The mineralogy can be described as dominated by the following species: 


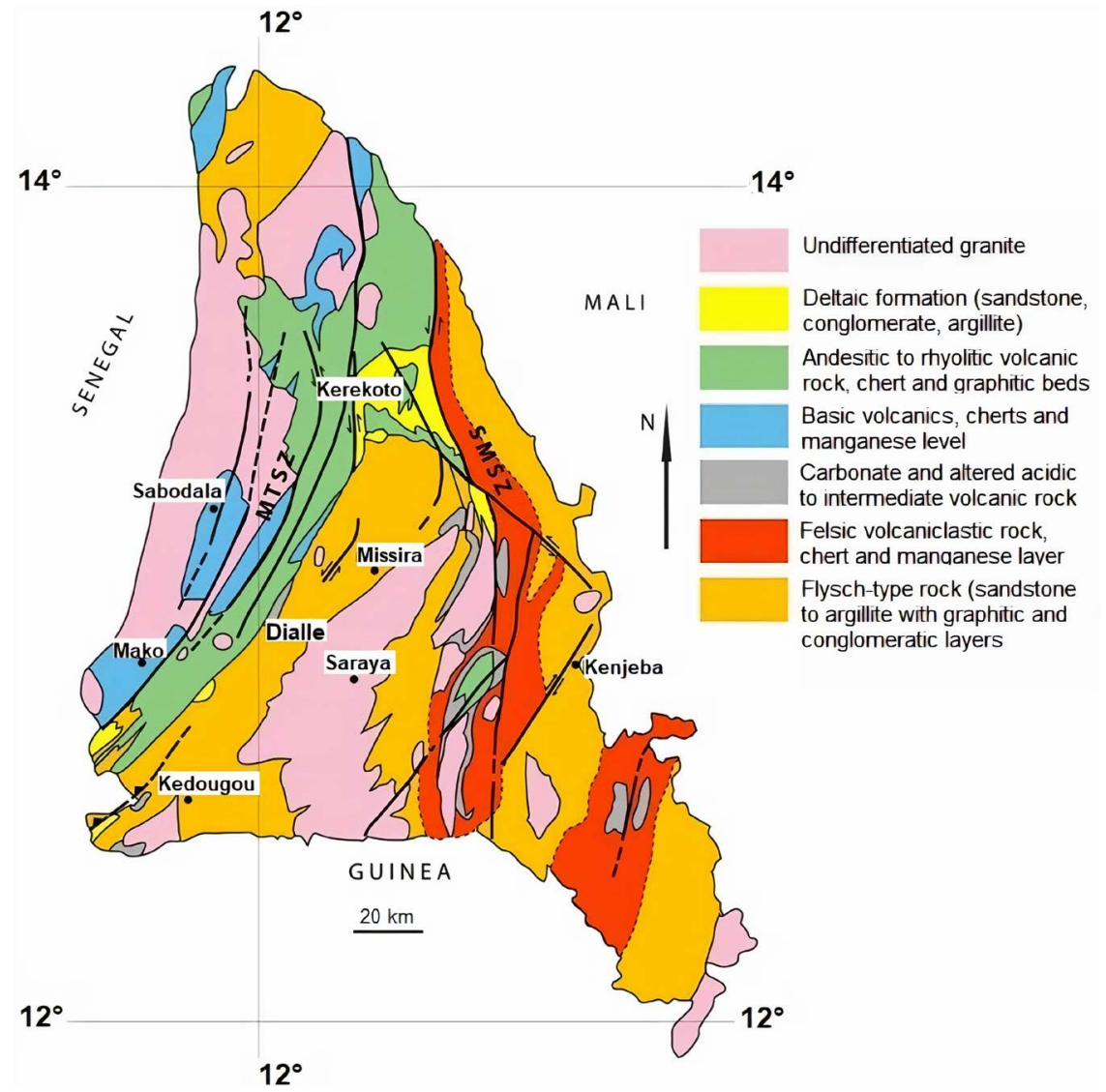

Figure 2. Geological map of the Kédougou-Kéniéba inlier (Modified) (Ledru et al., 1991).

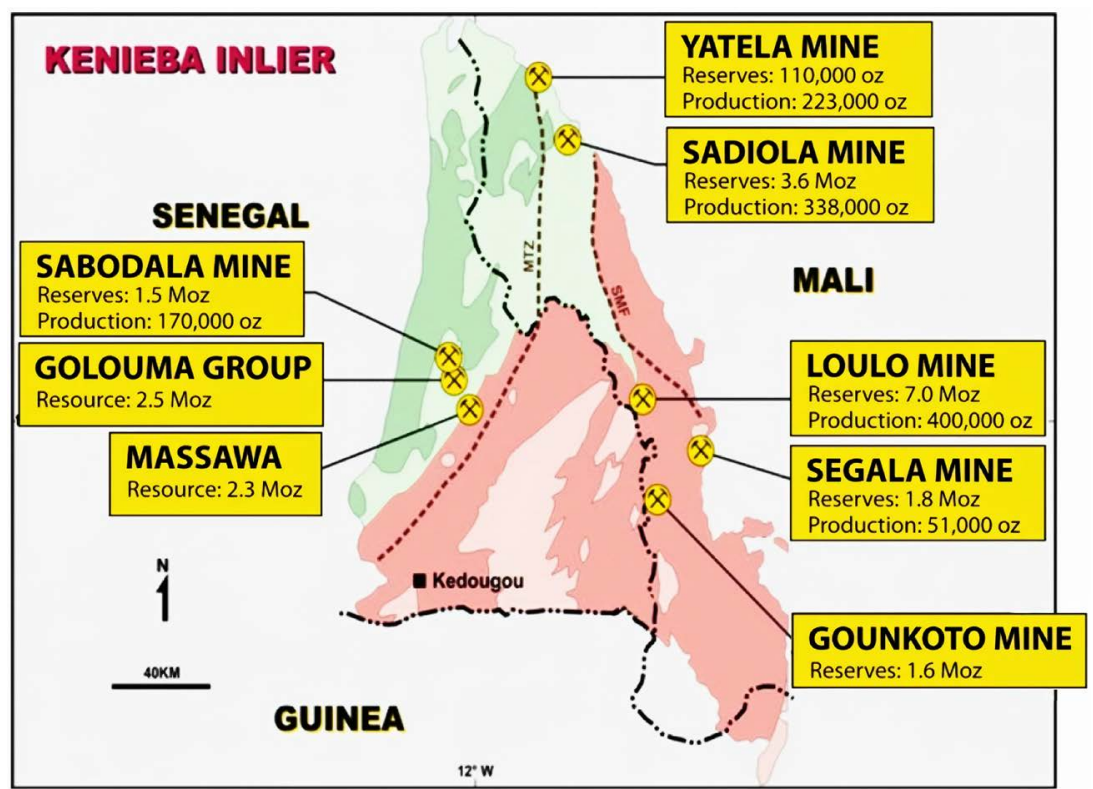

Figure 3. Minerogenic map for gold of the Kedougou Keniaba inlier (Stephenson et al., 2010).

- Ferromagnesian species likes $\mathrm{Fe} / \mathrm{Mg}$ rich pyroxenes and their alteration products (chlorite and secondary amphiboles) and plagioclase which are the 
major components of the mafic volcanic/plutonic and ultramafic (pyroxene) units;

- Chlorite, talc and accessory serpentine coming from ultramafic rock alterations;

- Silica varieties which dominate in the cherts, siltstones and felsic dykes' units.

The Sabodala deposit is characterized by multiple gold mineralization styles which all are associated with pyrite being hosted by quartz shear and quartz-carbonate extensional veins, disseminated in broad zones of carbonate-albite alteration surrounding shear veins or disseminated in hydraulic breccia with quartz-carbonate-albite matrix (Stephenson et al., 2010).

\subsection{Sabodala's Tailings Impoundment}

The tailings storage facility at Sabodala gold mine covers an approximate surface of 274 ha and is located in a valley which is closed by engineered embankments. Tailings are discharged in the form of slurries by spigots installed at regular distances on a pipe by which these slurries are pumped from the process plant. The spigots are switched on and off alternatively to enable a proper drying of the tailings and the water to decant at the centre of the TSF.

Figure 4 shows the location, in the TSF, of the 3 to 4 meters deep auger drill holes labelled with the collected fresh tailings sample numbers. Sample C002 was collected in drill hole A001, C004 in A002 and C006 in A003.

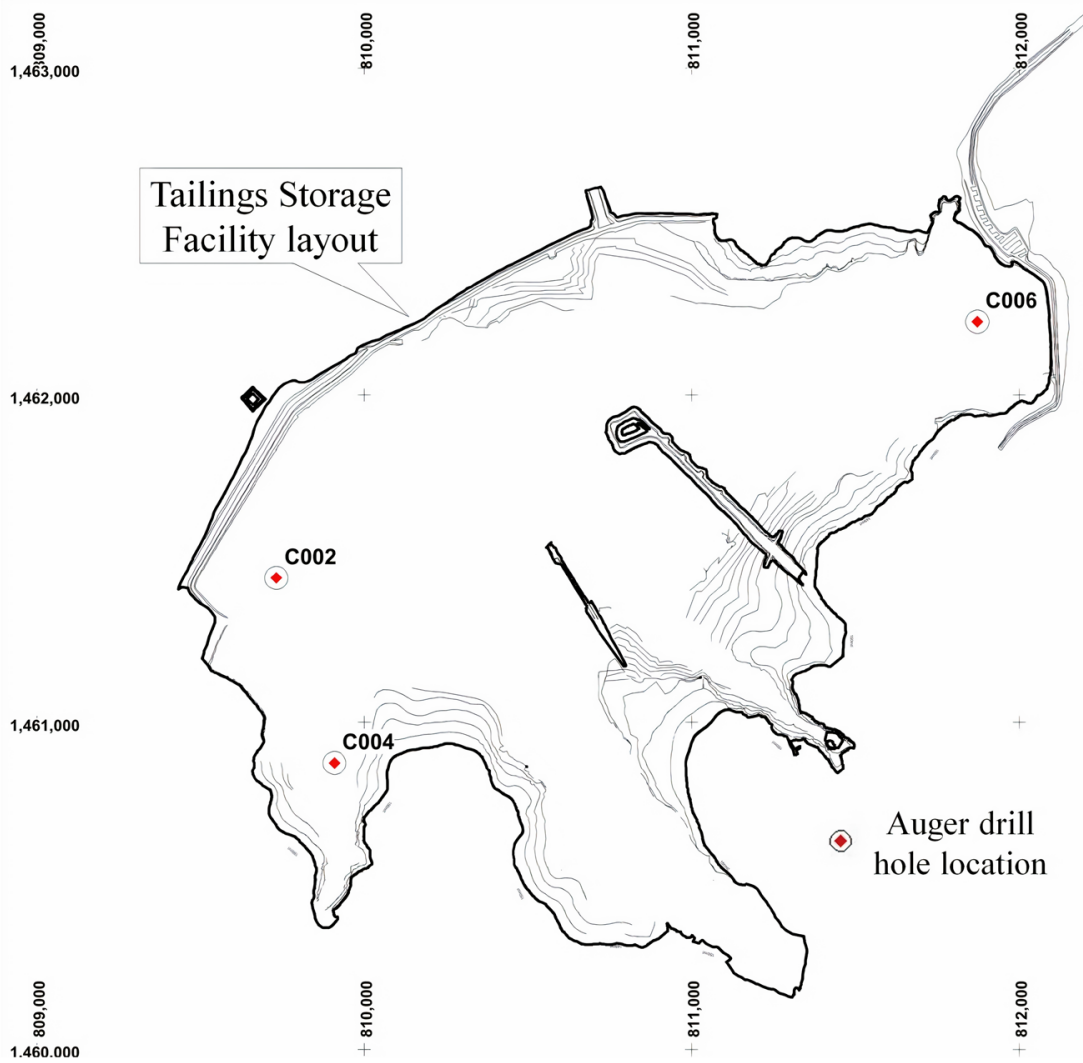

Figure 4. Auger drill holes location onto Sabodala's tailings storage facility layout. 


\section{Materials and Methodology}

\subsection{Sampling Procedure}

Three locations were selected to undertake auger drilling on the tailings. Due to the active deposition of tailings, the locations were limited to beach areas where the tailings where firm enough to safely take the weight of the drill personnel. For the need of the sampling, a hand auger was used to manually drill vertical holes enabling accessing all the horizons of the tailings impoundments with a maximum depth of 3.6 meters.

The auger's blade is surmounted by a metallic tube filled by the tailings as the drilling continues. The tailing material of each run is composited and place in plastic bags and then polywave bags. The paste $\mathrm{pH}$ and the electrical conductivity are recorded for each bag to monitor their variations with an increasing depth.

Fresh and oxidised material are first separated and after a vigorous homogenisation of each of them, a sample is collected in smaller plastic bag and sent to the laboratory for mineralogical and geochemical characterization. Due to thinness of the oxidised layer, samples of this layer carried out from the three holes (A001, A002 and A003) were mixed to produce a single composite oxide sample.

The four samples produced are labelled C001 (oxidised composite sample) and C002, C004, C006 (non-oxidised bulk samples for the three different holes).

\subsection{Field Measurements}

Sample paste $\mathrm{pH}$ and the electrical conductivity were determined in the field using the following method. A solution was prepared by mixing tailings with deionized water at the mass/mass ratio of 1:1 and then stirred manually until the homogeneity is reached. The mixture is then kept a room temperature (approximately $30^{\circ} \mathrm{C}$ ) for one hour before the measurement of the $\mathrm{pH}$ and the electrical conductivity using a HANNA instruments HI9829 Multi-parameter meter.

The measurement of field $\mathrm{pH}$ enables defining the current nature of the pore water of the tailings, likewise measurement of field electrical conductivity gives an approximation of the ionic strength, and hence major ion concentration within the tailings pore water.

\subsection{Sample Preparation}

Samples were dispatched to the ISO 17025 accredited ALS laboratory in Johannesburg for sample preparation and analysis. All samples were dried at $105^{\circ} \mathrm{C}$ for 24 hours prior to disaggregation. The following physical and chemical tests were undertaken:

- Particle size distribution analysis

- Whole rock multi element assay following strong acid digestion

- Bulk mineralogy by fine powder X-Ray Diffraction (XRD) with Rietveld refinement

- Carbon and sulphur speciation 
- Neutralising potential titration in accordance with the modified Sobek procedure with siderite correction.

Particle size distribution analyses were performed according to French standards NF P 94-056 (1996) and NF P 94-057 (1992) respectively by dry sieving and hydrometer method. The hydrometer method was applied to fraction passing the 80 microns sieve with the dry sieving method.

\subsection{X-Ray Diffraction Analysis}

All the samples were analysed using X-ray diffraction (XRD) technique and they were prepared using a back-loading preparation method. The samples were analysed with a PANalytical Empyrean diffractometer with PIXcel detector and fixed slits with $\mathrm{Fe}$ filtered $\mathrm{Co}-\mathrm{Ka}$ radiation. The phases were identified using X'Pert Highscore plus software. The relative phase amounts were estimated using the Rietveld method. The technique is unable to identify amorphous or poorly crystalline material (Chirwa, 2015).

\subsection{Whole Rock Analysis}

These tests were conducted by a commercial laboratory using Inductively Coupled Plasma (ICP) method. Part of the analytes were analysed using the Atomic Emission Spectroscopy (AES) option and the other part using the Mass Spectroscopy (MS) option of ICP. However, total carbon (including organic) and sulphur content were determined using the LECO instrument.

The major elements ( $\mathrm{Si}, \mathrm{Al}, \mathrm{Fe}, \mathrm{Ca}, \mathrm{Mg}, \mathrm{Na}, \mathrm{K}, \mathrm{Cr}, \mathrm{Ti}, \mathrm{Mn}, \mathrm{P}, \mathrm{Sr}$, and $\mathrm{Ba}$ ) are analysed using ICP-AES method with lithium borate and lithium tetra-borate flux being mixed with the sample to lower the fusion point of the mixture which is then fused in a furnace. The produced melt is dissolved in nitric and chlorohydrin acids.

The following base metals are also analysed using ICP-AES but with for acids (hydrofluoric, perchloric, nitric and hydrochloric acid) for digestion: $\mathrm{Ag}, \mathrm{Cd}$, $\mathrm{Co}, \mathrm{Cu}, \mathrm{Li}, \mathrm{Mo}, \mathrm{Ni}, \mathrm{Pb}, \mathrm{Sc}$ and $\mathrm{Zn}$.

The total carbon and sulphur are determined using Leco equipment and an infrared detection system.

For all other elements, ICP-MS which provides better results for lower concentrations were used. The digestion phase is the same than for major elements.

\subsection{Carbon and Sulphur Speciation}

Carbon and sulphur speciation was determined through combustion and infra-red detection method using LECO instrument. This method involves the determination of total sulphur and carbon both prior to and following a hydrochloric acid leach to dissolve inorganic (carbonate) carbon and sulphate sulphur respectively. Sulphide sulphur and organic carbon can then be calculated by difference. In addition, sulphur was also determined following sodium carbonate $\left(\mathrm{Na}_{2} \mathrm{CO}_{3}\right)$ leach which allows for the complete dissolution of sulphate minerals 
(including barite).

\subsection{Neutralisation Potential}

Based on the mineralogical and elemental results, the acid Neutralisation Potential (NP) of the sample was determined through titration with hydrochloric acid using the modified Sobek method with a siderite correction (Price, 2009; Sobek et al., 1978). In this test, the NP is determined by mixing the sample with hydrochloric acid of known quantity and concentration. The remaining acid is then measured by back titration to $\mathrm{pH} 8$ using $\mathrm{NaOH}$ solution following reaction with the sample. This gives the amount of acid consumed by the sample which is converted to NP in $\mathrm{CaCO}_{3}$ equivalents. For this test, the quantity of acid used depends on the Fizz rating which is determined visually by the operator.

Siderite correction was necessary due to the presence of siderite $\left(\mathrm{FeCO}_{3}\right)$ in the samples during mineralogical examination (see results section). Siderite correction involves the oxidation of liberated $\mathrm{Fe}^{2+}$ using hydrogen peroxide following the addition of $\mathrm{HCl}$ and prior to back titration with $\mathrm{NaOH}$.

\subsection{Geochemical Abundance Index (GAI)}

This index is calculated using the concentration of an element in the studied material and its concentration in a reference media (the earth crust, for this research work). The ratio between those two concentrations is noted " $r$ ".

The GAI is based on a log-2 scale and is expressed in 7 integer increment (from 0 to 6). It allows then to assess the relative enrichment of this element: An GAI of 0 implies that the ratio " $r$ " is smaller than 3 . For GAI values of $1,2,3,4,5$ and 6 respectively, $3<\mathrm{r} \leq 6,6<\mathrm{r} \leq 12,12<\mathrm{r} \leq 24,24<\mathrm{r} \leq 48$ and $48<\mathrm{r} \leq 96$.

\section{Results}

\subsection{Particle Size Distribution}

Sabodala's tailings are generally very fine and according to the European standard NF EN ISO 14688-1 (2003), they belong to the fine sandy loam grain size fraction. Figure 5 shows the results of particle size distribution analysis.

\subsection{Mineralogical Composition}

Results returned by the mineralogical analysis are shown in Table 1 and Figure 6 and shows the predominance of quartz and plagioclase in both oxidised and non-oxidised tailings. These two mineral phases content are oppositely higher in the oxidised (quartz) and fresh (plagioclase) tailings. The oxidised sample shows higher concentrations of secondary weathering minerals: kaolinite, goethite and talc.

Carbonate minerals are mainly represented by dolomite with minor siderite. The stoichiometry for the dissolution of dolomite and siderite is given by Equations (1) and Equation (2) showing that it consumes 1 mole of acidity for each mole of carbonate equivalent dissolved. Siderite is represented but not taken into 
Table 1. Quantitative mineralogical through XRD analysis (result in \% by weight).

\begin{tabular}{cccccc}
\hline Minerals & Chemical formulae & $\mathrm{C001}$ & $\mathrm{C002}$ & $\mathrm{C004}$ & $\mathrm{C006}$ \\
\hline Quartz & $\mathrm{SiO}_{2}$ & 44.86 & 35.67 & 29.8 & 28.5 \\
Plagioclase (mainly albite) & $(\mathrm{Na}, \mathrm{Ca})(\mathrm{Si}, \mathrm{Al})_{4} \mathrm{O}_{8}$ & 11.74 & 21.58 & 22.16 & 23.8 \\
Dolomite & $\mathrm{CaMg}\left(\mathrm{CO}_{3}\right)_{2}$ & 3.7 & 13.08 & 18.59 & 14.97 \\
Chlorite & $(\mathrm{Mg}, \mathrm{Fe})_{5}(\mathrm{Si}, \mathrm{Al})_{4} \mathrm{O}_{10}(\mathrm{OH})_{8}$ & 6.34 & 10.46 & 6.13 & 4.84 \\
Muscovite & $\mathrm{KAl}_{2}\left(\mathrm{AlSi}_{3} \mathrm{O}_{10}\right)(\mathrm{F}, \mathrm{OH})_{2}$ & 10.93 & 8.24 & 8.97 & 9.68 \\
Talc & $\mathrm{Mg}_{3} \mathrm{Si}_{4} \mathrm{O}_{10}(\mathrm{OH})_{2}$ & 4.04 & 3.3 & 3.7 & 2.76 \\
Kaolinite & $\mathrm{Al}_{2} \mathrm{Si}_{2} \mathrm{O}_{5}(\mathrm{OH})_{4}$ & 9.25 & 2.91 & 3.27 & 2.67 \\
Siderite & $\mathrm{FeCO}_{3}$ & 0.05 & 1.67 & 1.16 & 6.8 \\
Chalcopyrite & $\mathrm{CuFeS}_{2}$ & 0.74 & 1.55 & 1.61 & 1.24 \\
Pyrite & $\mathrm{FeS}_{2}$ & 0.46 & 1.22 & 1.98 & 1.42 \\
Pyrrhotite & $\mathrm{FeS}_{2}$ & 0.22 & 0.33 & 0 & 0.38 \\
Actinolite & $\mathrm{Ca}_{2}\left(\mathrm{Mg}_{2}, \mathrm{Fe}_{5} \mathrm{Si}_{8} \mathrm{O}_{22}(\mathrm{OH})_{2}\right.$ & 0 & 0 & 2.63 & 2.61 \\
Goethite & $\mathrm{FeO}(\mathrm{OH})$ & 7.67 & 0 & 0 & 0.38 \\
\hline
\end{tabular}

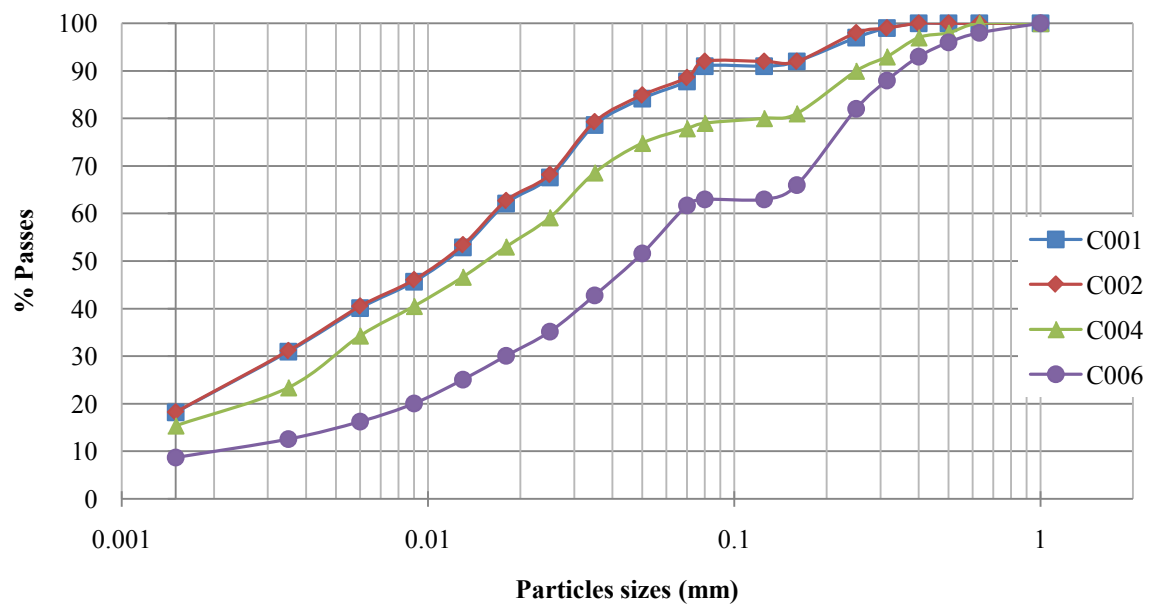

Figure 5. Particle size distribution of the Sabodala tailings.

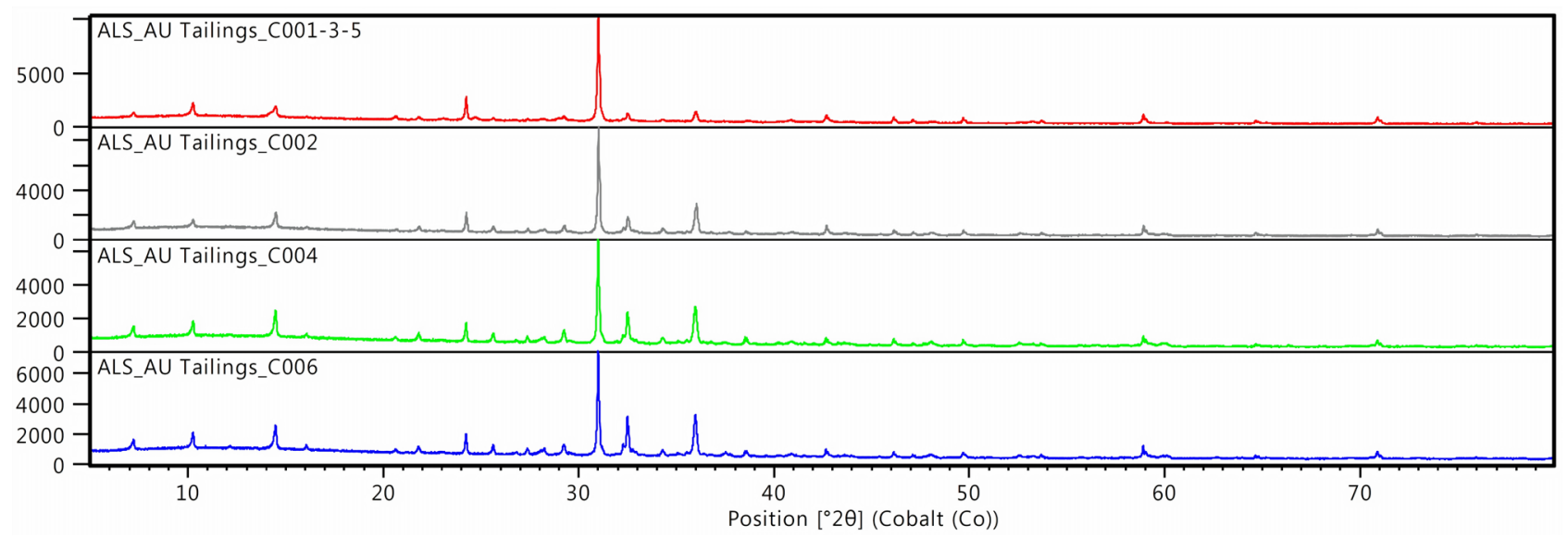

Figure 6. XRD diffractogram of 4 gold tailing sample. 
account for the NP given the fact that their contribution to the NP is suppressed by the acids produced by the hydrolysis of iron ions released by their dissolution. In general, carbonate minerals are more abundant in the fresh than in the oxidised tailings indicating that they have been partially consumed due to oxidation of sulphides and dissolution by rainwater.

$$
\begin{gathered}
\mathrm{CaMg}\left(\mathrm{CO}_{3}\right)_{2(\mathrm{~s})}+2 \mathrm{H}^{+} \rightarrow \mathrm{Ca}^{2+}+\mathrm{Mg}^{2+}+2 \mathrm{HCO}_{3}^{-} \\
\mathrm{FeCO}_{3(\mathrm{~s})}+0.5 \mathrm{O}_{2}+2 \mathrm{H}_{2} \mathrm{O} \rightarrow \mathrm{Fe}(\mathrm{OH})_{3}+\mathrm{HCO}_{3}^{-}
\end{gathered}
$$

Minerals contributing to the AP are mostly represented by pyrite and chalcopyrite and to a lesser extent by pyrrhotite with a total sulphides average content of $1.4 \%$ in oxidised tailings and $3.3 \%$ in non-oxidised tailings. The generation of acids $\left(\mathrm{H}^{+}\right.$equivalent) is directly or not consecutive to the oxidation of sulphides (Price, 2009). The Equations (3)-(5) give respectively the oxidation reaction for pyrite, chalcopyrite and pyrrhotite:

$$
\begin{gathered}
\mathrm{FeS}_{2(\mathrm{~s})}+7 / 2 \mathrm{O}_{2}+\mathrm{H}_{2} \mathrm{O} \rightarrow \mathrm{Fe}^{2+}+2 \mathrm{SO}_{4}^{2-}+2 \mathrm{H}^{+} \\
\mathrm{CuFeS}_{2(\mathrm{~s})}+7 / 2 \mathrm{O}_{2}+\mathrm{H}_{2} \mathrm{O} \rightarrow \mathrm{Fe}^{2+}+2 \mathrm{SO}_{4}^{2-}+2 \mathrm{H}^{+} \\
\mathrm{Fe}_{(1-x)} \mathrm{S}_{2(\mathrm{~s})}+7 / 2 \mathrm{O}_{2}+\mathrm{H}_{2} \mathrm{O} \rightarrow \mathrm{Fe}^{2+}+2 \mathrm{SO}_{4}^{2-}+2 \mathrm{H}^{+}
\end{gathered}
$$

Oxidation of chalcopyrite leads to release of sulphur and $\mathrm{Fe}^{2+}$ ions which are respectively oxidised and hydrolysed to produce acids. No sulphate minerals were identified by the mineralogical analysis.

The remaining mineral species occurring are mainly silicates which solubilities are variable but in general very low and therefore impact very weakly the acid base accounting (Price, 2009). The reduction in plagioclase feldspar albite together with the relative increase in the weathering product kaolinite indicates feldspar weathering as per the stoichiometry in Equation (6):

$$
2 \mathrm{NaAlSi}_{3} \mathrm{O}_{8}+2 \mathrm{H}^{+}+9 \mathrm{H}_{2} \mathrm{O} \rightarrow 2 \mathrm{Na}^{+}+4 \mathrm{H}_{4} \mathrm{SiO}_{4}+\mathrm{Al}_{2} \mathrm{Si}_{2} \mathrm{O}_{5}(\mathrm{OH})_{4}
$$

In this case the proton source can be either sulphuric acid derived from sulphide weathering as per Equation (3) above or derived from carbonic acid within rainwater. The rate of weathering of feldspar is surface area related and therefore the fine grinding accomplished during the metallurgical process will significantly enhance the mass weathering rate in proportion to the rate observed in the unprocessed ore. This in turn will likely enhance the overall available NP of the system.

\subsection{Field Paste $\mathrm{pH}$ and Electrical Conductivity}

The measurement of the paste $\mathrm{pH}$ in the field revealed a consistent alkaline state of the pore water with values ranging between 9 and 10. No variations were noticed with increasing depth or tailings nature (oxidised or reduced).

In the contrary, regarding the electrical conductivity, a considerable difference was noticed between oxidised tailings which returned values with an average of 
$300 \mu \mathrm{S} / \mathrm{cm}$ and fresh tailings with an average value of $103 \mu \mathrm{S} / \mathrm{cm}$. However, that variation wasn't regular with increasing depth. Figure 7 and Figure 8 shows the $\mathrm{pH}$ and EC value for the three holes (A001, A002 and A003) and for the composite oxidised sample (A001-2-3).

\subsection{Near Total Solid Phase Elemental Concentrations}

In order to assess their relative enrichments in the tailings, a Geochemical Abundance Index (GAI) was calculated for each element and for all analysed samples. This index is given by the following formula (Equation (7)) where "C" is the concentration of the element in the samples and " $S$ ", its reference content in the crust:

$$
\mathrm{GAI}=\log _{2} \frac{C}{1.5 \times S}
$$
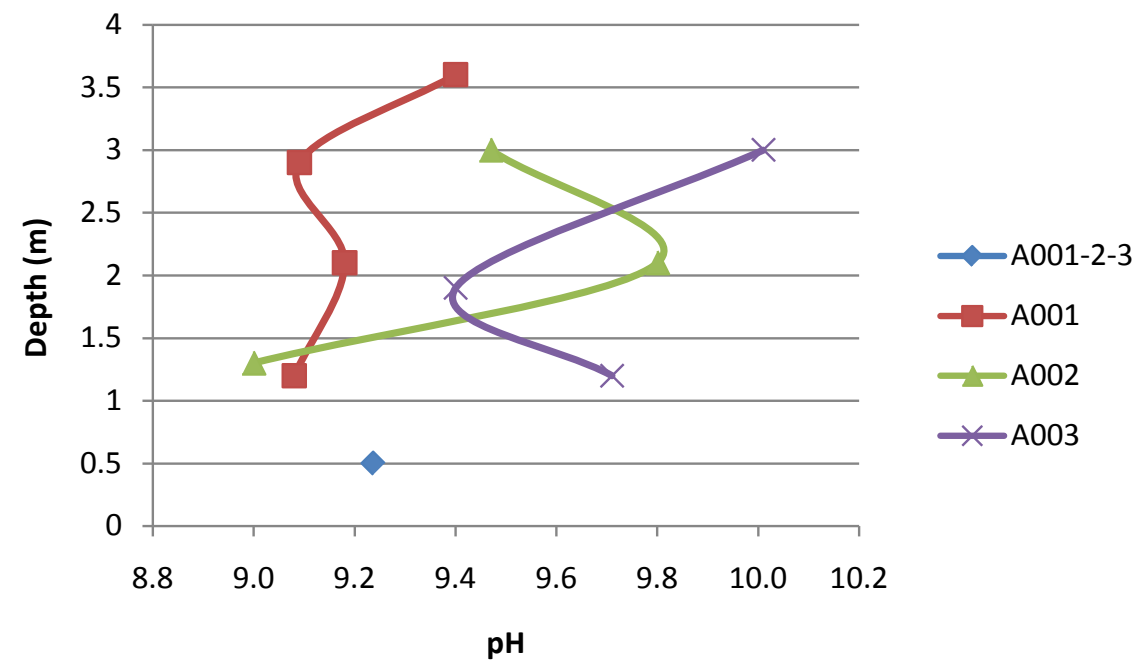

Figure 7. $\mathrm{pH}$ variation with depth.

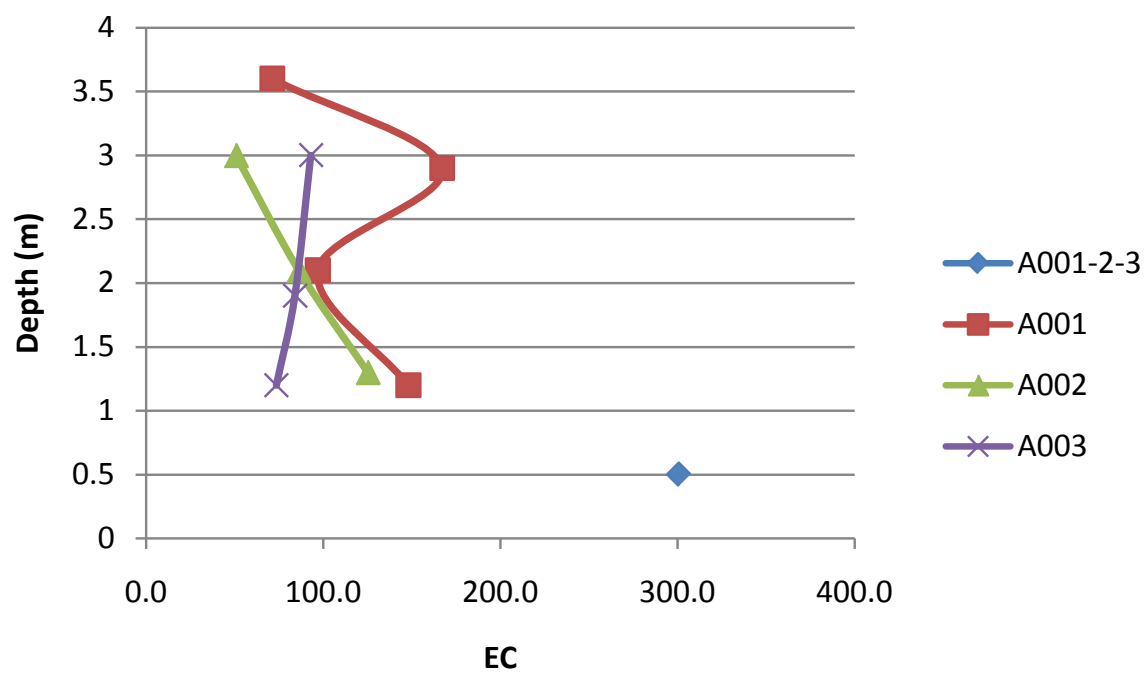

Figure 8. EC variation with depth. 
The GAI therefore compares the actual concentration of the element in the sample with its abundance in a relevant media such as crustal abundance (INAP, 2009). GAI greater or equal to 3 represent a significantly enriched element (12 to 96 times the median abundance) and therefore warrant special attention (INAP, 2009).

The median abundance of elements in crustal rocks given in "Principles of Geochemistry" (Mason \& Moore, 1982) has been used to calculate GAIs which results are shown in Table 2.

Carbon, selenium and tellurium are the only elements with GAI consistently greater than 3 (in oxidised and non-oxidised tailings). Chromium and tungsten on one hand and sulphur and molybdenum on the other hand have GAI greater than 3 respectively on the oxidised and fresh tailings.

\subsection{Acid Base Accounting and Prediction of Drainage $\mathrm{pH}$}

Acid Base Accounting (ABA) was used to assess the balance of acid generating to acid neutralising minerals within the tailings (Table 3 ). This then allows the determination of the expected long term behaviour of the tailings in terms of their potential to generate ARD.

Table 2. Near total solid phase elemental composition and GAI calculated for each sample.

\begin{tabular}{|c|c|c|c|c|c|c|c|c|c|c|}
\hline \multirow[t]{2}{*}{ Element } & \multirow[t]{2}{*}{ Unit } & \multirow{2}{*}{$\begin{array}{c}\text { Average } \\
\text { crustal } \\
\text { content }\end{array}$} & \multicolumn{4}{|c|}{$\begin{array}{l}\text { Elemental concentrations in } \\
\text { samples }\end{array}$} & \multicolumn{4}{|c|}{ Geochemical Abundance Index } \\
\hline & & & $\mathrm{C} 001$ & $\mathrm{C} 002$ & $\mathrm{C} 004$ & $\mathrm{C} 006$ & $\mathrm{C} 001$ & $\mathrm{C} 002$ & C004 & C006 \\
\hline $\mathrm{Ag}$ & ppm & 0.07 & $<0.5$ & $<0.5$ & $<0.5$ & $<0.5$ & & & & \\
\hline $\mathrm{Al}$ & $\%$ & 8.13 & 6.31 & 5.01 & 5.35 & 5.65 & 0 & 0 & 0 & 0 \\
\hline As & ppm & 1.8 & 6.5 & 1.4 & 1.8 & 1.3 & 1 & 0 & 0 & 0 \\
\hline $\mathrm{Ba}$ & $\%$ & 0.04 & 0.02 & 0.02 & 0.02 & 0.02 & 0 & 0 & 0 & 0 \\
\hline $\mathrm{Ba}$ & $\%$ & 0.04 & 0.019 & 0.016 & 0.016 & 0.017 & 0 & 0 & 0 & 0 \\
\hline $\mathrm{Bi}$ & ppm & 0.2 & 0.17 & 0.2 & 0.19 & 0.14 & 0 & 0 & 0 & 0 \\
\hline $\mathrm{C}$ & ppm & 200 & 9400 & 26,800 & 27,900 & 23,800 & 4 & 6 & 6 & 6 \\
\hline $\mathrm{Ca}$ & $\%$ & 3.63 & 1.96 & 4.98 & 5.09 & 4.49 & 0 & 0 & 0 & 0 \\
\hline $\mathrm{Cd}$ & ppm & 0.2 & $<0.5$ & $<0.5$ & $<0.5$ & $<0.5$ & & & & \\
\hline $\mathrm{Ce}$ & ppm & 60 & 22.1 & 17.6 & 19.9 & 22.1 & 0 & 0 & 0 & 0 \\
\hline Co & ppm & 25 & 65 & 39 & 57 & 38 & 0 & 0 & 0 & 0 \\
\hline $\mathrm{Cr}$ & ppm & 100 & 1440 & 350 & 290 & 230 & 3 & 1 & 0 & 0 \\
\hline Cs & ppm & 3 & 7.06 & 2.94 & 2.7 & 2.45 & 0 & 0 & 0 & 0 \\
\hline $\mathrm{Cu}$ & ppm & 55 & 124 & 85 & 100 & 80 & 0 & 0 & 0 & 0 \\
\hline Dy & ppm & 3 & 3.25 & 2.82 & 3.4 & 3.23 & 0 & 0 & 0 & 0 \\
\hline $\mathrm{Er}$ & ppm & 2.8 & 1.9 & 1.55 & 1.85 & 2.1 & 0 & 0 & 0 & 0 \\
\hline $\mathrm{Eu}$ & ppm & 1.2 & 1.02 & 0.84 & 0.87 & 0.99 & 0 & 0 & 0 & 0 \\
\hline
\end{tabular}




\section{Continued}

\begin{tabular}{|c|c|c|c|c|c|c|c|c|c|c|}
\hline $\mathrm{Fe}$ & $\%$ & 5 & 7.65 & 6.38 & 7.9 & 6.89 & 0 & 0 & 0 & 0 \\
\hline $\mathrm{Ga}$ & $\mathrm{ppm}$ & 15 & 14.2 & 11.9 & 12.3 & 12.6 & 0 & 0 & 0 & 0 \\
\hline $\mathrm{Gd}$ & $\mathrm{ppm}$ & 5.4 & 3.75 & 2.88 & 3.14 & 3.48 & 0 & 0 & 0 & 0 \\
\hline $\mathrm{Ge}$ & $\mathrm{ppm}$ & 1.5 & $<5$ & $<5$ & $<5$ & $<5$ & & & & \\
\hline $\mathrm{Hf}$ & ppm & 3 & 2.3 & 1.9 & 2.5 & 2.8 & 0 & 0 & 0 & 0 \\
\hline $\mathrm{Hg}$ & $\mathrm{ppm}$ & 0.08 & 0.012 & 0.017 & 0.01 & 0.018 & 0 & 0 & 0 & 0 \\
\hline Ho & $\mathrm{ppm}$ & 1.2 & 0.69 & 0.58 & 0.75 & 0.68 & 0 & 0 & 0 & 0 \\
\hline In & ppm & 0.1 & 0.043 & 0.032 & 0.036 & 0.031 & 0 & 0 & 0 & 0 \\
\hline $\mathrm{K}$ & $\%$ & 2.59 & 1.5 & 0.84 & 0.94 & 0.95 & 0 & 0 & 0 & 0 \\
\hline $\mathrm{La}$ & $\mathrm{ppm}$ & 30 & 10.3 & 7.7 & 8.6 & 9.2 & 0 & 0 & 0 & 0 \\
\hline $\mathrm{Li}$ & ppm & 20 & 20 & 20 & 20 & 10 & 0 & 0 & 0 & 0 \\
\hline $\mathrm{Lu}$ & ppm & 0.5 & 0.25 & 0.22 & 0.27 & 0.29 & 0 & 0 & 0 & 0 \\
\hline $\mathrm{Mg}$ & $\%$ & 2.09 & 1.57 & 3.17 & 3.01 & 2.55 & 0 & 0 & 0 & 0 \\
\hline $\mathrm{Mn}$ & $\%$ & 0.09 & 0.09 & 0.09 & 0.1 & 0.09 & 0 & 0 & 0 & 0 \\
\hline Mo & ppm & 1.5 & 8 & 23 & 25 & 16 & 1 & 3 & 3 & 2 \\
\hline $\mathrm{Na}$ & $\%$ & 2.83 & 0.93 & 1.66 & 1.91 & 2.27 & 0 & 0 & 0 & 0 \\
\hline $\mathrm{Nb}$ & $\mathrm{ppm}$ & 20 & 4.8 & 4.1 & 5.2 & 5.8 & 0 & 0 & 0 & 0 \\
\hline $\mathrm{Nd}$ & $\mathrm{ppm}$ & 28 & 12.5 & 10 & 11 & 11.9 & 0 & 0 & 0 & 0 \\
\hline $\mathrm{Ni}$ & ppm & 75 & 481 & 150 & 156 & 114 & 2 & 0 & 0 & 0 \\
\hline $\mathbf{P}$ & $\%$ & 0.1 & 0.06 & 0.04 & 0.06 & 0.07 & 0 & 0 & 0 & 0 \\
\hline $\mathrm{Pb}$ & ppm & 13 & 16 & 8 & 6 & 6 & 0 & 0 & 0 & 0 \\
\hline Pr & $\mathrm{ppm}$ & 802 & 3.07 & 2.35 & 2.61 & 2.87 & 0 & 0 & 0 & 0 \\
\hline $\mathbf{R b}$ & $\mathrm{ppm}$ & 90 & 60.8 & 27.6 & 31.6 & 30.2 & 0 & 0 & 0 & 0 \\
\hline $\operatorname{Re}$ & $\mathrm{ppm}$ & 0.001 & 0.003 & 0.004 & 0.003 & 0.002 & 1 & 1 & 1 & 0 \\
\hline$S$ & ppm & 260 & 2300 & 6000 & 15400 & 9100 & 2 & 3 & 5 & 4 \\
\hline $\mathrm{Sb}$ & ppm & 0.2 & 0.59 & 0.18 & 0.19 & 0.17 & 0 & 0 & 0 & 0 \\
\hline $\mathrm{Sc}$ & ppm & 22 & 31 & 24 & 26 & 23 & 0 & 0 & 0 & 0 \\
\hline $\mathrm{Se}$ & ppm & 0.05 & 0.6 & 0.8 & 1.4 & 1 & 3 & 3 & 4 & 3 \\
\hline $\mathrm{Si}$ & $\%$ & 27.72 & 28.11 & 25.12 & 22.45 & 24.79 & 0 & 0 & 0 & 0 \\
\hline $\mathrm{Sm}$ & ppm & 6 & 3.19 & 2.8 & 3.03 & 3.24 & 0 & 0 & 0 & 0 \\
\hline Sn & ppm & 2 & 1 & 1 & 1 & 1 & 0 & 0 & 0 & 0 \\
\hline $\mathrm{Sr}$ & ppm & 375 & 100 & 100 & 200 & 100 & 0 & 0 & 0 & 0 \\
\hline $\mathrm{Sr}$ & $\mathrm{ppm}$ & 375 & 70.7 & 135 & 143.5 & 119.5 & 0 & 0 & 0 & 0 \\
\hline $\mathrm{Ta}$ & ppm & 2 & 0.3 & 0.2 & 0.3 & 0.3 & 0 & 0 & 0 & 0 \\
\hline $\mathrm{Tb}$ & ppm & 0.9 & 0.59 & 0.49 & 0.53 & 0.53 & 0 & 0 & 0 & 0 \\
\hline $\mathrm{Te}$ & ppm & 0.01 & 0.3 & 0.47 & 0.65 & 0.43 & 4 & 4 & 5 & 4 \\
\hline Th & ppm & 7.2 & 1.48 & 0.89 & 1.03 & 1.03 & 0 & 0 & 0 & 0 \\
\hline $\mathrm{Ti}$ & $\%$ & 0.44 & 0.51 & 0.44 & 0.55 & 0.53 & 0 & 0 & 0 & 0 \\
\hline
\end{tabular}




\begin{tabular}{ccccccccccc}
\multicolumn{1}{l}{ Continued } \\
\hline $\mathrm{Tl}$ & $\mathrm{ppm}$ & 0.5 & 0.04 & 0.03 & 0.02 & 0.02 & 0 & 0 & 0 & 0 \\
$\mathrm{Tm}$ & $\mathrm{ppm}$ & 0.5 & 0.32 & 0.24 & 0.29 & 0.27 & 0 & 0 & 0 & 0 \\
$\mathrm{U}$ & $\mathrm{ppm}$ & 1.8 & 0.58 & 0.32 & 0.48 & 0.36 & 0 & 0 & 0 & 0 \\
$\mathrm{~V}$ & $\mathrm{ppm}$ & 135 & 239 & 196 & 219 & 199 & 0 & 0 & 0 & 0 \\
$\mathrm{~W}$ & $\mathrm{ppm}$ & 1.5 & 34 & 13 & 16 & 16 & 3 & 2 & 2 & 2 \\
$\mathrm{Y}$ & $\mathrm{ppm}$ & 33 & 18.5 & 15.9 & 18.2 & 18.6 & 0 & 0 & 0 & 0 \\
$\mathrm{Yb}$ & $\mathrm{ppm}$ & 3.4 & 1.81 & 1.48 & 1.84 & 1.82 & 0 & 0 & 0 & 0 \\
$\mathrm{Zn}$ & $\mathrm{ppm}$ & 70 & 96 & 86 & 80 & 70 & 0 & 0 & 0 & 0 \\
$\mathrm{Zr}$ & $\mathrm{ppm}$ & 165 & 85 & 73 & 83 & 96 & 0 & 0 & 0 & 0 \\
\hline
\end{tabular}

Table 3. Carbon and sulphur assay results together with ABA calculations.

\begin{tabular}{ccccccccccccc}
\hline Sample & Fizz rating & $\mathrm{pH}$ & $\mathrm{NNP}$ & $\mathrm{NP}$ & $\mathrm{MPA}$ & $\begin{array}{c}\text { Ratio } \\
\text { NP/MPA }\end{array}$ & $\begin{array}{c}\text { Total } \\
\text { sulphur }\end{array}$ & $\begin{array}{c}\text { Sulphur } \\
\text { (carbonate } \\
\text { leachable) }\end{array}$ & $\begin{array}{c}\text { Sulphur } \\
\text { (HCl leachable) }\end{array}$ & $\begin{array}{c}\text { Sulphide } \\
\text { sulphur }\end{array}$ & $\begin{array}{c}\text { Inorganic } \\
\text { carbon }\end{array}$ & $\mathrm{CO}_{2}$ \\
\hline Unit & Unity & Unity & \multicolumn{2}{c}{$\mathrm{tCaCO}_{3} / 1 \mathrm{Kt}$} & Unity & $\%$ & $\%$ & $\%$ & $\%$ & $\%$ & $\%$ \\
\hline $\mathrm{C001}$ & 2 & 8.2 & 54 & 62 & 8.1 & 7.63 & 0.26 & 0.06 & 0.07 & 0.2 & 0.82 & 3 \\
$\mathrm{C002}$ & 2 & 8.3 & 147 & 167 & 20 & 8.35 & 0.64 & 0.07 & 0.04 & 0.57 & 2.42 & 8.9 \\
$\mathrm{C004}$ & 2 & 8.4 & 124 & 172 & 48.1 & 3.57 & 1.54 & 0.02 & $<0.01$ & 1.52 & 2.52 & 9.3 \\
$\mathrm{C006}$ & 2 & 8.9 & 125 & 152 & 26.6 & 5.72 & 0.85 & $<0.01$ & 0.01 & 0.85 & 2.24 & 8.2 \\
\hline
\end{tabular}

In order to be conservative, the calculation of the acid generation capacity of the samples was based on the Maximum Potential Acidity (MPA). The calculation of MPA assumes that the total sulphur content of the sample is present as, and behaves like, the di-sulphide mineral pyrite $\left(\mathrm{FeS}_{2}\right)$ and reacts completely to form sulphate and ferric hydroxide during oxidation. MPA $\left(t \mathrm{CaCO}_{3} / 1 \mathrm{Kt}\right)$ is given by the following Equation (8):

$$
\text { MPA }=\% \text { Total sulphur } \times 31.25 \text { (Price, 2009) }
$$

The Neutralization Potential can also be calculated using the total inorganic carbon $\left(\mathrm{CO}_{3}-\mathrm{NP}\right)$ which is considered to be totally related to calcite minerals (Price, 2009). However, this alternative wasn't used given the fact that the mineralogical analysis did show that most of the inorganic carbon is not related to calcite.

The comparison of the NP and the MPA (i.e. NP/MPA and NNP) are used as the main criteria to give a prediction on the $\mathrm{pH}$ of future drainage produced from the tailings which can be then characterised as Non Potentially Acid Generating (Non PAG) and Potentially Acid Generating (PAG) (Price, 2009).

The choice of the method used to predict the nature of the drainage is partly based on the results from the mineralogical and elemental analysis. However, despite the fact that no sulphate minerals did occur in the mineralogical analysis, a limited amount of sulphate sulphur ( $\mathrm{HCl}$ leachable) was stated in the $\mathrm{ABA}$ test. 
The sulphide sulphur represents $77 \%$ and $96 \%$ of the total sulphur respectively in the oxidised and reduced material. The calculated MPA is relatively low in the oxidised material and much higher in the reduced one.

Total carbon from the elemental analysis was compared with the inorganic carbon from the $\mathrm{ABA}$ test to evaluate the proportion of inorganic carbon in the sample. Calculated values range from $87 \%$ to $94 \%$ with a median of $90.5 \%$ of inorganic carbon.

The average NP determined using the bulk acid neutralization procedure is 62 $\mathrm{tCaCO}_{3} / \mathrm{Kt}$ and $164 \mathrm{tCaCO}_{3} / \mathrm{Kt}$ respectively for oxidised and reduced material.

For all samples, ratio between NP and MPA exceeds 3 (units) and the Net Neutralization Potential (NNP) which is given by the Equation (9) is positive and very high.

$$
\mathrm{NNP}=\mathrm{NP}-\mathrm{MPA} \quad(\text { Price, 2009) }
$$

\section{Discussions}

The higher proportion of quartz and secondary minerals (kaolinite, talc and goethite) in the oxidised tailings is indicative of chemical weathering which partially explains the lower proportion of minerals like plagioclases, carbonates and sulphides. In addition, the removal of a large portion of dolomite has resulted in proportional increase in elements such as $\mathrm{Cr}, \mathrm{W}$ and $\mathrm{Cs}$ which are generally associated with more refractory minerals. In addition, we see an enrichment of As and $\mathrm{Sb}$ which are readily enriched through adsorption to iron oxides.

However, it shall be noted that the decrease in the proportion of plagioclase in the oxidised tailing is quite substantial and it is most likely only partially related to the weathering that took place after their settlement in the TSF. This means that part of the feldspar minerals was altered before the processing of the oxidised ore.

Carbonates are mainly represented by dolomite and sulphides by pyrite and chalcopyrite. Sulphates are missing in the mineralogical analysis results but sulphate-sulphur is stated in the ABA test; this suggests the very little amount of sulphates compared to sulphides which most likely are responsible for most part of the acids generated.

Despite the fact that the procedure used to determine the paste $\mathrm{pH}$ is not a standardized one, it gives a relatively accurate idea on the current $\mathrm{pH}$ of the tailings. The tailings can be considered as net alkaline. Pore water in the oxidised zones is more mineralized with a higher electrical conductivity.

Carbon and sulphur high GAIs along with molybdenum relative enrichment can be explained by the presence in relatively high percentage in the ore of dolomite and sulphides minerals (mostly pyrite and chalcopyrite). Molybdenum is frequently incorporated in the major sulphides like pyrite and its proportions vary consistently with the sulphide ones between the oxidised (lower) and fresh (higher) tailings. The same reason (mineralogy) explains as well GAI of chromium which is known to occur in relatively high percentage in mafic facies. In- 
deed, $\mathrm{Cr}$ substitutes very easily for $\mathrm{Fe}$ and $\mathrm{Mg}$ and is partitioned into pyroxene during the earliest stages of crystal fractionation resulting in its enrichment in ultramafic rocks (Klein \& Hurlbut, 1998). This enrichment subsists even after alteration of pyroxene into secondary minerals like chlorite. Figure 9 compares the enrichment of each element in the oxidised and fresh tailings.

Selenium and tellurium are both metalloids that are very common as trace element in sulphide minerals like pyrite (Klein \& Hurlbut, 1998). Their abundance in the tailings is most likely closely related to sulphides relative enrichment in the ore. On the other hand, tellurides are also known to be very common in mesothermal greenstone hosted gold deposits (Gao et al., 2015) like Sabodala.

The bulk acid neutralization is, for all analysed samples, at least three times higher than the acids generation potential. This fact is coherent with proportions of minerals releasing respectively bases and acids.

\section{Conclusion}

The differences in the mineralogy between the oxidised and the fresh tailings are most likely mainly related to weathering of the oxidised tailings that led consecutively to oxidation of sulphides, generation of acids, dissolution of carbonate resulting in neutralisation of acids and alteration of part of feldspars into kaolinite. These weathering reactions result in the dissolution of ionic compounds which are confirmed by the higher electrical conductivity that suggest a high ionic strength.

The enrichment of other secondary minerals, notably talc, chlorite and oxides are most likely formed during the weathering of the material prior to its disposal in the tailings.

The mineralogical composition explains also the enrichment of carbon, selenium

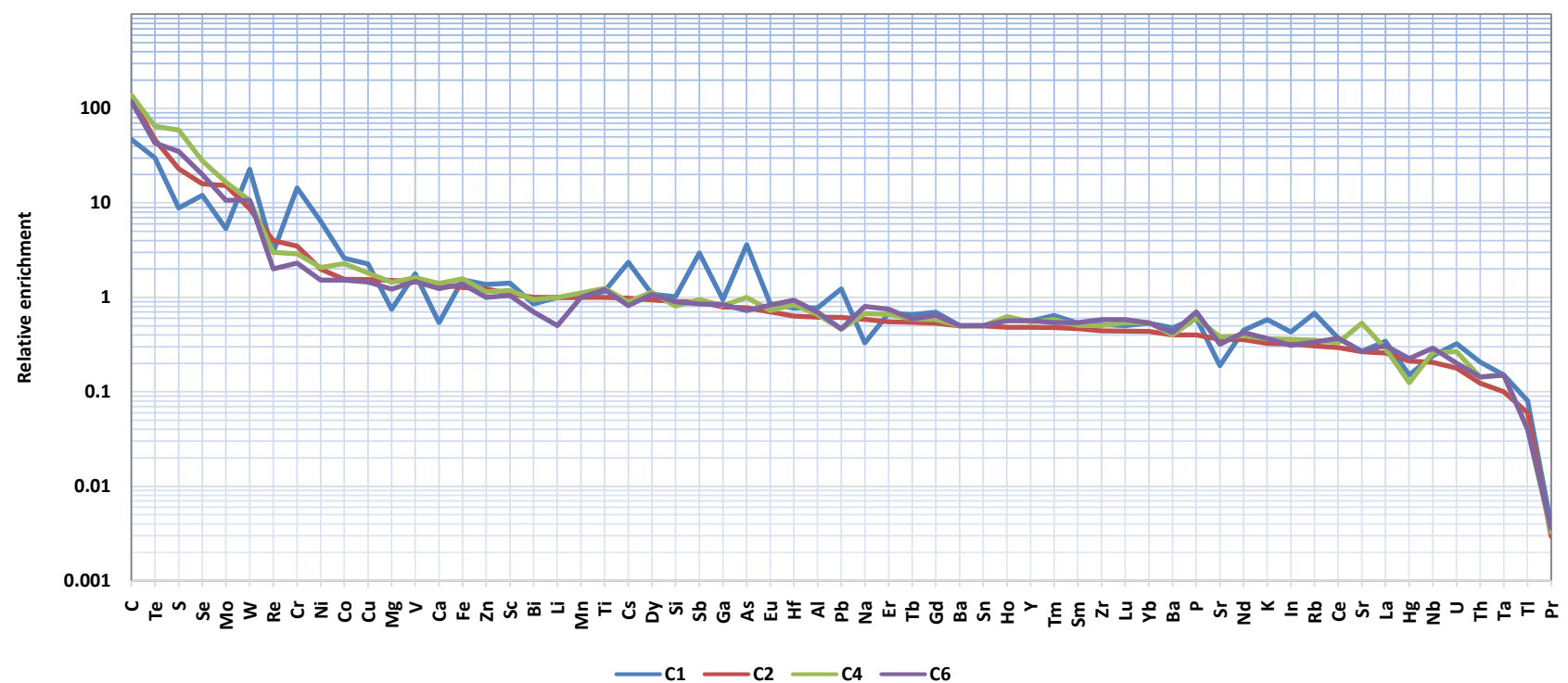

Figure 9. Elemental enrichment relative to average crustal abundance. 
and tellurium in all types of tailings and sulphur and molybdenum in non-oxidised tailings. The source of high chromium proportion in the oxidised tailings would then be the result of the increase of ultramafic facies in the oxidised ore.

After several years (up to six years) of exposition of the tailings in the TSF, in all analysed samples, the NP is always three times higher than the MPA. This suggests that these tailings are of Non PAG type and most likely will continue to produce an alkaline drainage. This state is consistent with the net alkalinity revealed by $\mathrm{pH}$ measurement on pore water pressure.

The mineralogical investigation undertaken in the current study included only XRD analysis. Although the Reitveld refinement method was used, which significantly enhances the sensitivity of the method, the method is limited in its sensitivity to detection of minor mineral phases (less than say 1\%) and also for the identification of trace element substitution within crystal lattice of major minerals. It is recognised that further evaluation of the samples using quantitative SEM with electron dispersive X-Ray analysis would be a definitive approach to identifying the deportment of trace elements within the minerals present in the samples. Enrichment of tungsten could then probably be more accurately explained.

\section{Acknowledgements}

This study was conducted at the Earth Sciences Institute of the Cheikh Anta Diop University of Dakar and with the support of Teranga Gold Corporation as part of its corporate social responsibility program.

\section{Conflicts of Interest}

The authors declare no conflicts of interest regarding the publication of this paper.

\section{References}

Chirwa, T. (2015). ALS Minerals Report No. ALSCR-15-07.

Gao, S., Xu, H., Zhang, D., Shao, H., \& Quan, S. (2015). Ore Petrography and Chemistry of the Tellurides from the Dongping Gold Deposit, Hebei Province, China. Ore Geology Reviews, 64, 23-34. https://doi.org/10.1016/j.oregeorev.2014.06.010

Gueye, M., Ngom, P. M., Diène, M., Thiam, Y., Siegesmund, S., Wemmer, K., \& Pawlig, S. (2008). Intrusive Rocks and Tectono-Metamorphic Evolution of the Mako Paleoproterozoic Belt (Eastern Senegal, West Africa). Journal of African Earth Sciences, 50, 88-110. https://doi.org/10.1016/j.jafrearsci.2007.09.013

Hirdes, W., \& Davis, D. W. (2002). U-Pb Geochronology of Paleoproterozoic Rocks in the Southern Part of the Kédougou-Kénieba Inlier, Senegal, West Africa: Evidence for Diachronous Accretionary Development of the Eburnean Province. Precambrian Research, 118, 83-99. https://doi.org/10.1016/S0301-9268(02)00080-3

Klein, C., \& Hurlbut, C. S. (1998). Manual of Mineralogy (21st ed., 681 p.). Hoboken, NJ: John Wiley and Sons Inc.

Ledru, P., Pons, J., Milési, J. P., Feybesse, J. L., \& Johan, V. (1991). Transcurrent Tectonics and Polycyclic Evolution in the Lower Proterozoic of Senegal-Mali. Precambrian Re- 
search, 50, 337-354. https://doi.org/10.1016/0301-9268(91)90028-9

Mason, B., \& Moore, C. B. (1982). Principles of Geochemistry (4th ed., 344 p.). New York: John Wiley and Sons.

NF EN ISO 14688-1 (2003). Geotechnical Investigation and Testing-Identification and Classification of Soil-Part 1: Identification and Description.

NF P 94-056 (1996). Soil: Investigation and Testing-Granulometric Analysis-Dry Sieving Method after Washing.

NF P 94-057 (1992). Soil: Investigation and Testing_Granulometric Analysis-Hydrometer Method.

Peel, M. C., Finlayson, B. L., \& McMahon, T. A. (2007). Updated World Map of the Köppen-Geiger Climate Classification. Hydrology and Earth System Sciences, 11, 1633-1644. https://doi.org/10.5194/hess-11-1633-2007

Price, W. A. (2009). Prediction Manual for Drainage Chemistry from Sulphidic Geologic Materials, MEND Report 1.20.1 (579 p.).

Rhys, D. (2010). Report on May 2010 Geological Work at the Sabodala Mine (35 p.). Surrey: Panterra Geoservices Inc.

Sobek, A. A., Schuller, W. A., Freeman, J. R., \& Smith, R. M. (1978). Field and Laboratory Methods Applicable to Overburdens and Minesoils (204 p.). Environmental Protection Technology Series.

Stephenson, P. R., Shannon, J. M., O'Connor, B., Riles, A., \& Ebrahimi, A. (2010). Sabodala Gold Project, Senegal, West Africa: Technical Report for Teranga Gold Corporation.

The International Network for Acid Prevention (INAP) (2009). Global Acid Rock Drainage Guide (GARD Guide). http://www.gardguide.com

TROPICA Environmental Consultants (2006). Projet d'Exploitation d'Or, d'Argent et de Substances Connexes a Sabodala de SMC: Etude d'Impact Environnemental et Social (186 p.). 